\title{
https://doi.org/10.48009/2_iis_2006_280-283 \\ KNOWLEDGE WORK AND IT OUTSOURCING: IS SOME WORK RETURNING TO THE UNITED STATES?
}

\author{
Arthur C. McAdams, Fairfield University, amcadams@ mail.fairfield.edu \\ Winston Tellis, Fairfield University, winston@ mail.fairfield.edu
}

\begin{abstract}
This paper explores the relationship between Knowledge Work and IT outsourcing which gained visibility during the 2004 US Presidential election campaign. The outsourcing phenomenon is maturing and companies have learned what is appropriate to outsource and for what reasons. That is causing some tasks to return to the US. Understanding Knowledge Work will help companies make decisions regarding effective outsourcing.
\end{abstract}

Keywords: Knowledge Work, Outsourcing, IT Value Proposition, IT Skill Sets

\section{INTRODUCTION}

It has been almost fifty years since Peter Drucker and Fritz Machlup independently coined the term knowledge worker. Since then, the concept of the knowledge worker and managing knowledge has been studied and developed by academics and practitioners. As the new economy matures and businesses move into several geographical locations, organizations find themselves struggling for an integrated and managed organizational knowledge solution.

Knowledge is a continuously evolving collection of explicit information and tacit insight that provides a framework for decision making [7]. The need for improved customer service, collaboration between employees and partners, and decreased cycle times as a competitive edge (even across countries) has driven the need for knowledge management [26]. Research has indicated that rapid knowledge transfer is critical for organizational excellence, especially in disciplines that rely on intellect, in the new economy [11]. Organizations that deliver services, such as IT departments, may need to adopt similar programs in the near future as a technique to address employee turnover and retirement.

Employees may withhold sharing information based on the fear of losing an individual competitive edge within the organization, especially during trends of downsizing and rightsizing [9]. Technology has enabled organizations to produce goods in disparate geographical areas with fewer employees. Concepts such as learning curves, experience curves, and manufacturing progress functions have existed for many years and are built from a belief that something must be measured before it can be improved [22]. These lessons may be applied to an organization to bolster many areas of production but it is not yet an effective tool for measuring qualitative factors such as customer service.

Unfortunately, many of the benefits of knowledge management are difficult to quantify. Liam Fahey and Laurence Prusak [12] recommend focusing on the outcomes of a knowledge management program rather than force a set of meaningless metrics. Fahey and Prusak warn that placing erroneous quantifiable metrics may undermine knowledge management because the metrics may minimize the critical human element. Demonstrating cause-and-effect may be the most effective way to measure knowledge capital. For instance, performance metrics could include measuring the response time to customer queries and measuring customer and user satisfaction [26].

\section{IT EFFECTIVENESS}

Thornton May [18] stated that the crisis facing IT departments was the result of inadequate communication skills among senior IT managers that subsequently leads to ambiguous expectations and an unclear purpose of IT within the organization. This assertion aligns with other experts who have indicated that engineers need to acquire certain competencies, primarily communication and nontechnical, to function successfully as productive business associates [13]. Information technology departments offer services to other departments within the organization as well as the entire organization and that introduces many different relationships [2]. The role of a CIO needs to evolve from a technologist to a business consultant with a technology background [23]. In this way, knowledge management, IT effectiveness, and outsourcing are related.

Researchers and practitioners have consistently identified the discomfort and dissatisfaction between business professionals and IT professionals [15]. As a 
group, IT professionals often resist influences from outside the technology profession, thus leading to a perception of IT professionals as social outcasts [16]. The perceptual and cultural gap between business professionals and IT professionals has been described as a cultural war [25]. The resulting frustration within the IT profession, caused by a seemingly perpetual lack of understanding and communication with the business community, has led to a growing cynicism within experienced IT managers [5].

Measuring the effectiveness of IT and assessing gains in productivity are much different than simply counting the number of application systems in the organization [3]. An IT department that simply places software packages on servers and desktops, without regard for the skills of the end-users or the workflow processes, will run the risk of layering additional costs on the organization without adding value [14]. Often IT managers fail to identify many of the costs beyond the initial hardware and software costs such as implementation effort, maintenance, and training that can all lead to additional costs or reduced benefits from a new system [1].

\section{NEW ROLES WITHIN IT AND SOME RETURNING WORK}

While openness to outsourcing is important, it is probably not the most important issue facing executives as organizations need to adopt new thinking to compete in the current and future highly competitive environment. Experts have recommended that IT professionals, especially IT managers, should stop speaking in technological terms (jargon), which often confuses and alienates business professionals, and start actively playing a role in communicating the purpose and role of technology with business executives [18]. This misconception of the purpose and role that technology plays in the economy is primarily a result of a communication breakdown between business managers and technologists as there is a profound difference between building a workforce that is computer literate versus information literate [10]. Systems engineers often force business professionals to become computer literate by designing computerfriendly but user-unfriendly interfaces that confound and annoy business professionals [5].

The image of IT is closely linked to the success rate of projects, and the success rate of projects is significantly affected by organizational dynamics and structure [24]. Delivering projects that meet cost parameters, align with time estimates, and match the agreed-upon features is vitally important to the success of business ventures [21]. Information technology departments that fail to deliver solutions that meet the needs of the business will further exacerbate the relationship problem.

The image of IT is further tarnished by financial management issues. In many organizations IT is viewed as uncontrolled discretionary administrative overhead [8]. Often these measures are incomplete because less tangible benefits such as intellectual property and organizational processes are omitted [27]. Unfortunately, in most organizations IT is measured using traditional quantitative (mostly financial) metrics such as return on investment (ROI) that are often dysfunctional and misleading [19]. These financial issues continue to erode the relationship between IT and business professionals [18].

In some cases the perceived outcome of IT initiatives may be driven by the way business professionals feel they were treated during the implementation [17]. For instance, business professionals may perceive that the implementation of a new IT system was a failure based on administrative issues [17]. Moreover, many of the perceptions of whether a system is successful or not can be driven by social relationships within the organization [6]. Employees have informal beliefs about other employees through organizational social networks that that introduce unseen variables to perceived success [6]. Thus it is often the lack of consistent communication within the various levels of management and the employees of the organization that cause the systems projects to fail. In many cases, the confluence of two or more of the above factors could result in the senior management actively seeking to outsource some or all of the IT operations.

\section{CONCLUSION}

Initially, companies in the U.S. and Europe reviewed cost figures, particularly in times of financial challenge, and saw what appeared to be an obvious candidate for cost reduction. CIOs must in the future identify with the company rather than the technology [26]. Failure to do so, could cause IT to be viewed as not integral to the core business, and hence could be assigned to an external organization with little or no loss of functionality. Not all outsourced operations are successful; following the lead of corporations such as Microsoft, Intel, IBM and others, Dell carefully examined the financial benefit of sending some work to India. Comparing the salaries of Indian employees at a Call Center, Dell could improve its profit margin by significantly reducing the cost of 
providing support to customers. However, in 2003 Dell was forced to stop using a Call Center in India for corporate customers after "an onslaught of complaints... due to thick accents and scripted answers..." [4]. Again in 2004 Dell dropped a Call Center in Bangalore, India because according Dell CEO Mott “...the Bangalore Center was unable to deal satisfactorily with the volume of calls..." [20].

It is now clearer that merely cost reduction may not be the optimal reason for considering outsourcing. Further, firms need to arrive at the decision to outsource after a systematic development methodology. Such a methodology would uncover the users' true needs with active participation by the IT department in the decision to seek an external source. Experience has shown that well developed specifications are imperative to successful outsourcing projects. Programmers in India, while both competent and cost effective at coding, may not fulfill all the valuable attributes-such as consultative services-provided by the U.S. employees. Therefore, while the mechanical aspects of a project may be met by outsourcing, the customer's broader requirements may not be satisfied. Looking forward, business and IT executives may want to broaden their perception of the IT value proposition.

\section{REFERENCES}

1. Barreau, D. (2001). The hidden costs of implementing and maintaining information systems. The Bottom Line, 14(4), 207-212.

2. Brancheau, J., Janz, B., Wetherbe, J. (1996, June). Key issues in information systems management: 1994-95 SIM Delphi results. MIS Quarterly, 20(2), 225-242.

3. Cardinali, R. (1998). Assessing technological productivity gains: Benson and Parker revisited. Logistics Information Management, 11(2), 8992.

4. CNN.Com (2003, November 26). Dell cancels Indian tech support. Retrieved June 12, 2006, from

http://www.cnn.com/2003/TECH/biztech/11/24/ dell.call.centers.ap/.

5. Cooper, A. (2004). The Inmates are running the Asylum. Indianapolis, IN: Sams Publishing.

6. Cross, R., Davenport, T., Cantrell, S. (2003). The social side of performance. MIT Sloan Management Review, 45(1), 20-22.

7. Davenport, T., Prusak, L. (2000). Working Knowledge: How Organizations Know What They Know. Cambridge, MA: Harvard Business School Press.
8. Day, J. (1996). An executive's guide to measuring I/S. Strategy and Leadership, 24(5), 39-41.

9. Desouza, K., Awazu, Y. (2003). Knowledge management: HR management systems can help track and distribute information throughout the organization. HR Magazine, 48(11), 107-111.

10. Drucker, P. (2002). Managing the Next Society, New York: St. Martin's Press.

11. English, M., Baker, W. (2006). Rapid knowledge transfer: The key to success. Quality Progress, 39(2), 41-48.

12. Fahey, L., Prusak, L. (1998). The Eleven Deadliest Sins of Knowledge Management. California Management Review, 40, 265-275

13. Garvin, D. (1993). Building a learning organization. In Harvard Business Review on Knowledge Management, 47-80. Boston: Harvard Business School Publishing.

14. Hammer, M., Champy, J. (2003). Reengineering the Corporation: A Manifesto for Business Revolution. New York: HarperCollins Publishers Inc.

15. Kwak, M. (2001). Technical skills, people skills: It's not either/or. MIT Sloan Management Review, 42(3), 16.

16. Kwantes, C., Boglarsky, C. (2004). Do occupational groups vary in expressed organizational culture preferences? International Journal of Cross Cultural Management, 4(3), 335-354.

17. Marble, R. (2003). A system implementation study: Management commitment to project management. Information Management, 4, 111123.

18. May, T. (1995). Chief information officer ABCs. Information Management Computer Security, 3(5), 23-25.

19. May, T. (1997). The death of ROI: Re-thinking IT value measurement. Information Management \& Computer Security, 5(3), 90-94.

20. McCue, A. (2004, March 31). Dell admits it has "learned its lesson." Retrieved June 12, 2006, from http://news.com.com/2100-1001_35182611.html.

21. Milosevic, D., Inman, L., Ozbay, A. (2001). Impact of project management standardization on project effectiveness. Engineering Management Journal, 13(4), 9-16.

22. Odom, C., Starns, J. (2003, August). How do you measure success? KMWorld, 12. Retrieved March 15, 2006, from http://www.kmworld.com/publications/magazine /index.cfm?action=readarticleArticle_I...

23. Overby, S. (2003, October). The incredible shrinking CIO. CXO Media Inc. Retrieved 
March 15, 2006, from http://www.cio.com/archive/101503/shrinking.ht $\mathrm{ml}$

24. Rivard, S., Raymond, L., Bergeron, Aubin, M. (1999). Project manager's influence tactics and authority: A comparison across project structures. ACM Press, 19/20(4/1), 6-20.

25. Tai, L., Phelps, R. (2000). CEO and CIO perceptions of information systems strategy:
Evidence from Hong Kong. European Journal of Information Systems, 9, 163-172.

26. Turban, E., King, D., Lee, J., Warkentin M., Chung, H. (2002). Electronic Commerce: A Management Perspective. Upper Saddle Ridge NJ: Prentice-Hall.

27. Utunen, P. (2003). Identify, measure, visualize your technology assets. Research Technology Management, 46(3), 31-39. 